\title{
NILAI-NILAI PENDIDIKAN AGAMA ISLAM MULTIKULTURAL DALAM MASYARAKAT MUSLIM TENGGER
}

\author{
Oleh: Imron Muhadi \\ Kementrian Agama Pasuruan \\ Email : imronmuhadi003@gmail.com
}

\begin{abstract}
Abstrak
Orang Tengger yang beragama Islam masih menganut kepercayaan ngelmu sebagai warisan leluhur mereka. Mereka masih mempercayai hitungan hitungan yang berkaitan dengan hari baik dan hari buruk untuk tujuan tujuan tertentu semisal pernikahan dan sebagainya. Banyak tokoh-tokoh masyarakat muslim Tengger mengatakan bahwa Tengger tidaklah dapat dipisahkan dengan tradisi serta adat istiadat yang diwariskan secara turun temurun, agama tidak lagi menjadi penghalang untuk melakukan kegiatan kegiatan upacara adat dan tradisi turun temurun yang diwariskan oleh nenek moyang orang Tengger. Justru dengan melestarikan upacara adat serta tradisi yang ada, masyarakat tengger dapat hidup rukun berdampingan secara damai. Ogoh-ogoh adalah upacara perayaan keagamaan umat Hindu sebelum merayakan hari raya Nyepi. Perayaan Nyepi ditandai dengan tidak adanya aktifitas kegiatan sehari hari dan bahkan lampu penerangan di daerah tersebut dipadamkan untuk beberapa saat (waktu).
\end{abstract}

Kata kunci: nilai-nilai, pendidikan agama Islam, multikulturalisme, tradisi, budaya lokal

\section{Abstract}

The Tengger people who are Muslim still adhere to the belief of ngelmu as their ancestral heritage. They still believe in counts relating to good days and bad days for certain purposes such as marriage and so on. Many Tengger Muslim community leaders said that Tengger cannot be separated from traditions and customs inherited from generation to generation, religion is no longer a barrier to carrying out traditional ceremonies and hereditary traditions inherited by the ancestors of the Tengger people. Therefore by preserving the traditional ceremonies and traditions that exist, the Tengger community can live in harmony side by side in peace. Ogohogoh is a religious ceremony for Hindus before celebrating Nyepi. The Nyepi celebration was marked by the absence of daily activities and even the lights in the area were put out for a period of time.

Keywords: values, Islamic religious education, multiculturalism, tradition, local culture 


\section{PENDAHULUAN}

Tengger merupakan wilayah geografis yang berada dikaki Gunung Bromo Jawa Timur. Pada awalnya, orang orang Hindu Waisya yang beragama Brahma bertempat tinggal di pantai pantai disekitar wilayah yang sekarang disebut dengan Kota Pasuruan dan Probolinggo. Setelah agama Islam masuk ke tanah Jawa yang dibawa oleh saudagar saudagar Islam yang kemudian dikenal dengan para wali dan atau Wali Songo maka keberadaan mereka (orang orang Hindu Waisya) merasa terusik maka kemudian mereka memilih untuk mencari daerah yang sulit dijangkau oleh manusia (pendatang) yakni daerah pegunungan untuk kemudian mereka manamakan dirinya sebagai tiang tengger.

Selama ini ada asumsi, bahwa kuatnya toleransi di masyarakat Tengger tidaknya terbatas pada persoalan adat istiadat local, tetapi tercermin pula soal penyikapan atau perilaku beragama. Misalnya seorang tokoh Hindu Tengger bernama Sopoyono, warga desa Wonokitri, Tosari, mempelopori berdirinya Mushalla di Gunung Bromo, Sopoyono ikut gelisah mendengar keluhan wisatawan muslim mengunjungi Gunung Bromo kesulitan mencari tempat ibadah.

Dalam temuan awal juga diindikasikan, bahwa eksistensi atau kondisi muslim Tengger mengalami dinamika yang cukup lumayan atau menarik. Hal demikian ini dianggap wajar atau logis karena keragaman keyakinan atau agama yang dianut dan budaya masyarakat tengger jumlahnya banyak. Muslim Tengger paham akan posisinya sehingga tidak akan memisahkan diri dengan menonjolkan identitas keagamaanya atau tidak menunjukkan sikap klaim kelompok dan kebenaran. Masyarakat demikian dapat dinilai dengan pandangan tokoh psikologi humanis Abraham Maslow yang menyebut, bahwa manusia memiliki potensi untuk maju dan berkembang. Melalui teori kebutuhan yang Ia kemukakan manusia memiliki kebutuhan dasar (basic needs) yang dibentuk menjadi 5 hirarki. Meliputi fisiologis, rasa aman, kasih sayang, harga diri dan mengekspresikan diri. ${ }^{1}$

\section{METODE PENELITIAN}

Pendekatan yang digunakan dalam penelitian adalah pendekatan kualitatif. Pendekatan kualitatif dipilih karena penelitian yang dilakukan berlatar alamiah. Pendekatan kualitatif merupakan proses penelitian yang menghasilkan data deskriptif berupa kata-kata tertulis atau lisan dari orang dan perilaku yang dapat diamati. Dalam hal ini adalah melakukan penelitian untuk mendapatkan data-data terkait dengan kehidupan masyarakat muslim

\footnotetext{
${ }^{1}$ Maslow, Motivation and Personality. Jakarta: Rajawali. 2010), 49.
} 
tengger baik data tertulis berupa arsip atau dokumentasi maupun data hasil pengamatan dilokasi penelitian dan aktifiktas masyarakat serta para tokoh yang mengetahui. Karena esensi dari penelitian ini adalah untuk memahami secara mendalam proses dan makna dari peristiwa yang berlangsung, sehingga jenis penelitiannya adalah etnografi. Selain alasan tersebut, etnografi dipilih karena kini semakin popular dalam dunia pendidikan. Yang dipandang mampu memahami secara mendalam sebuah proses dan makna dari sebuah peristiwa dalam lingkungan social budaya termasuk pendidikan

Pada penelitian ini desain yang digunakan peneliti adalah fenomenologi. Pendekatan fenomenologi sebagai desain penelitian telah digunakan secara luas dalam ilmu-ilmu sosial termasuk pendidikan. Jenis penelitian yang peneliti pilih adalah fenomenologi hermeneutik. Beberapa pakar penelitian menekankan ${ }^{2}$ bahwa dalam pendekatan fenomenologi hermeneutik peneliti tidak hanya mendeskripsikan makna pengalaman informan penelitian, tetapi juga melakukan interpretasi terhadap pengalaman tersebut.

\section{PEMBAHASAN}

Temuan hasil penelitian dibahas secara berurutan mengenai alasan masyarakat muslim Tengger menerima nilai-nilai pendidikan agama Islam multicultural dengan adat tradisi Tengger dan mempertahankan nilai-nilainilai yang ada yaitu: (1) adat tradisi tengger mengandung nilai-nilai multikulturalisme, (2) terdapat nilai-nilai kearifan lokal dalam toleransi beragama, (3) ada nilai-nilai multikulturalisme dalam keragaman agama dan budaya lokal masyarakat Kecamatan Tosari, (4) kerukunan umat beragama pada muslim Tengger sangat kokoh, (5) mempertahankan nilai-nilai Islam dalam keragamaan pemeluk agama dan budaya, (6) menjaga dinamika eksistensi muslim tengger di tengah keragaman agama dan budaya, (7) memperkokoh toleransi umat beragama, (8) menyusun strategi mempertahankan eksistensi muslim tengger dalam keragaman agama dan budaya.

\section{Alasan Masyarakat Muslim Tengger Menerima Nilai-Nilai Pendidikan Agama Islam Multikultural}

Alasan masyarakat muslim Tengger menerima adat tradisi Tengger dalam mempertahankan eksistensinya: (1) adat tradisi tengger mengandung nilai-nilai multikulturalisme, (2) terdapat nilai-nilai kearifan lokal dalam toleransi beragama, (3) ada nilai-nilai multikulturalisme dalam keragaman

${ }^{2}$ W. John Creswell, 2015. Penelitian Kualitatif dan Desain Riset: Memilih diantara Lima Pendekatan, (Yogyakarta. Pustaka Pelajar, 2015), 108. 
agama dan budaya lokal masyarakat Kecamatan Tosari, (4) kerukunan umat beragama pada Muslim Tengger sangat kokoh, penjelasan masing-masing alasan adalah sebagai berikut:

Pertama, adat tradisi yang masih berlaku sangat kuat dikalangan masyarakat Tengger baik yang beragama Hindu maupun sudah menjadi muslim, bahwa : sekeluarga agamanya berbeda-beda, orang tua mendukung dan membiarkan pilihan agama anaknya, saling membantu dalam soal keperluan keagamaan, perayaan, selamatan baik berupa tenaga maupun harta, saling berkunjung saat hari raya bahkan perkawinan beda agama. Apakah adat tradisi Tengger ini sesuai dengan tata pergaulan yang telah diatur dalam hukum Islam? Apa manfaatnya bagi muslim Tengger yang masih tetap mempertahankan adat tradisi tersebut? Tentu untuk menjawabnya harus didasarkan pada perspektif Islam dan kearifan lolal.

Kedua, nilai-nilai kearifan lokal dalam toleransi beragama pada masyarakat Tosari. Alasan muslim Tengger menerima adat tradisi Tengger di tengah-tengah keragaman pemeluk agama dan budaya, karena dalam adat tradisi Tengger terdapat nilai-nilai kearifan lokal yang diwariskan oleh para leluhur yang dapat memperkuat toleransi beragama di masyarakat Tengger Kecamatan Tosari. Nilai-niai kearifan lokal yang dimaksud adalah walat, isin dan gentenan. Dalam kaitan ini, Zuhairi Misrawi ${ }^{3}$ memahami toleransi sebagai sikap saling menghargai, menghormati keragaman budaya dan perbedaan kebebasan berekspresi, termasuk dalam berkeyakinan. Dalam Islam, Nabi Muhammad Saw. merupakan teladan yang baik dalam mengimplementasikan pendidikan toleransi yang merangkul semua etnis, agama tanpa membedakan warna kulit dan suku bangsa. Secara historis perkawinan Nabi Muhammad Saw. Dengan istri-istri yang berbeda etnis, dan latar belakang agama dan status sosial merupakan sebuah realitas pendidikan nilai multikultural, yakni toleransi. Sebut saja Shofiyah (wanita/perempuan mulia yang beragama Yahudi) sebelum dinikahi Rasulullah, Maria bin Sam'un (yang berbangsa Koptik dari Mesir) yang juga merupakan seorang budak (dari stratifikasi sosial termasuk kelas bawah) tawanan perang. Teman-teman bergaul Nabi yang tidak melihat perbedaan status, seperti Bilal Bin Rabah (budak berkulit hitam), Salman al Farizi (berbangsa Persi) dan masih banyak lagi contoh pergaulan nabi yang menggambarkan pendidikan toleransi yang dilakukan.

${ }^{3}$ Zuhairi Misrawi, Membumikan Toleransi al-Quran; Inklusivisme, Pluralisme dan Multikulturalisme, (Jakarta: Moslem Moderate Society. 2010), 1 
Ketiga, nilai-nilai multikulturalisme dalam keragamaan agama dan budaya lokal masyarakat kecamatan Tosari. Di dalam sebuah masyarakat, tentu saja ada banyak kelompok masyarakat yang memiliki karakteristik yang berbeda beda satu sama lainnya. Perbedaan-perbedaan karakteristik yang dimilikinya tersebut biasanya berkaitan dengan tingkat stratifikasi sosial serta diferensiasi. Masyarakat yang seperti ini lah yang dikenal dengan masyarakat multikultural.

Keempat, kerukunan umat beragama pada masyarakat muslim Tengger yang kokoh. Sebagian besar kerukunan antar umat bearagama di Kecamatan Tosari Kabupaten Pasuruan, masyarakatnya dikenal sebutan suku tengger tergolong sangat baik, hal ini terlihat bahwa responden yang memiliki alternatif jawaban yang sangat baik sebanyak 6 orang $(60 \% \%)$ dan responden yang memiliki jawaban baik sebanyak 4 orang (40) sebagaimana paparan hasil wawancara untuk mengukur kondisi kerukunan umat beragama di masyarakat muslim Tengger Kecamatan Tosari. Ada korelasi antara tradisi lokal yang ada di suku Tengger seperti sayan, gentenan, ngelawuh, anjangsana, turun dan mumupun. Selain itu kuatnya kerukunan umat beragama di daerah ini karena ada tradisi upacara adat yang sangat besar, seperti barikan, karo, unan-unan dan entas-entas. Tradisi-tradisi semacam ini masih berkembang dan diikuti masyarakat Tengger yang beragama Hindu dan Islam. Kuatnya toleransi di masyarakat Tengger tidaknya terbatas pada persoalan adat istiadat lokal, tetapi tercermin pula soal agama. Seorang tokoh Hindu Tengger bernama Sopoyono, warga desa Wonokitri, Tosari, mempelopori berdirinya Mushalla di Gunung Bromo, Sopoyono ikut gelisah mendengar keluhan wisatawan muslim mengunjungi Gunung Bromo kesulitan mencari tempat ibadah. Kini Mushalla telah berdiri kokoh dibangun atas kerjasama Laznas dengan Bank Syariah Mandiri.

\section{Muslim Tengger Mempertahankan Nilai-nilai Pendidikan Agama Islam Multikultural}

Cara mempertahankan eksistensi muslim Tengger di tengah-tengah keragaman keyakinan dan budaya sebagaimana dipaparkan bab sebelum adalah; 1) mempertahankan nilai-nilai Islam dalam keragamaan pemeluk agama dan budaya, 2) menjaga dinamika eksistensi muslim tengger di tengah keragaman agama dan budaya, 3) memperkokoh toleransi umat beragama, 4) menyusun strategi mempertahankan eksistensi muslim tengger dalam keragaman agama dan budaya. pembahasan terhadap hal tersebut sebagai berikut:

Pertama, mempertahankan nilai-nilai Islam dalam keragamaan pemeluk agama dan budaya. Ketika Islam masuk ke tanah Jawa melalui 
Wali Songo, tidak ada yang menyatakan dilakukan dengan cara paksaan ataupun kekerasan. Masyarakat yang ketika itu banyak yang memeluk Hindu, menerima kedatangan para wali dengan tangan terbuka. Karena kemampuan adaptasi para wali yang mampu memahami budaya lokal ketika itu, penyebaran Islam di tanah Jawa bisa terjadi tanpa harus melalui kekerasan. Bahkan akulturasi antar budaya bisa kita lihat hingga saat ini. Hal ini menunjukkan Islam dan budaya lokal bisa saling menyatu satu (konvegentif) dengan yang lainnya.

Kedua, menjaga dinamika eksistensi muslim Tengger di tengah keragaman agama dan budaya. Eksistensi muslim tengger mengalami dinamika yang cukup lumayan, hal tersebut wajar karena keragaman keyakinan atau agama yang dianut dan budaya masyarakat Tengger jumlahnya banyak. Muslim Tengger paham akan posisinya sehingga tidak akan memisahkan diri dengan menonjolkan identitas keagamaanya. Kondisi yang demikian itu dilakukan untuk menghindari persaingan yang tajam antara kelompok dan kelompok Hindu, sehingga, dalam kegiatan ritual adat mereka masih sering berpartisipasi, terutama dalam pembiayaan atau menyumbangkan bahan-bahan yang digunakan untuk ritual.

Ketiga, memperkokoh toleransi umat beragama. Dalam Peraturan Bersama Menteri Agama dan Menteri Dalam Negeri Nomor 9 Tahun 2006/ Nomor 8 Tahun 2006 Tentang Pedoman Pelaksanaan Tugas Kepala Daerah/Wakil Kepala Daerah dalam Pemeliharaan Kerukunan Umat Beragama, Pemberdayaan Forum Kerukunan Umat Beragama, dan Pendirian Rumah Ibadat disebutkan ${ }^{4}$ bahwa kerukunan umat beragama adalah keadaan hubungan sesama umat beragama yang dilandasi toleransi, saling pengertian, saling menghormati, menghargai kesetaraan dalam pengamalan ajaran agamanya dan kerjasama dalam kehidupan bermasyarakat, berbangsa dan bernegara di dalam Negara Kesatuan Republik Indonesia berdasarkan Pancasila dan Undang-Undang Dasar Negara Republik Indonesia Tahun 1945. Muhaimin ${ }^{5}$ menyatakan dengan kekeluargaan atau model kerukunan demikian, maka terciptalah ukhuwah fi ubudiyah, ukhuwah fi insaniyah, ukhuwah fi wathaniyah dan ukhuwah fi din al-Islam.

${ }^{4}$ Peraturan Bersama Menteri Agama dan Menteri Dalam Negeri Nomor 9 Tahun 2006/ Nomor 8 Tahun 2006 Tentang Pedoman Pelaksanaan Tugas Kepala Daerah/Wakil Kepala Daerah dalam Pemeliharaan Kerukunan Umat Beragama, Pemberdayaan Forum Kerukunan Umat Beragama, dan Pendirian Rumah Ibadat

${ }^{5}$ Muhaimin, Paradigma pendidikan Islam (upaya mengefektifkan pendidikan agama di sekolah). (Bandung: Remaja Rosdakarya, 2008), 76, 
Keempat, menyusun strategi mempertahankan eksistensi muslim Tengger dalam keragaman agama dan budaya. Sebagai kelompok minoritas, muslim tengger tetap menunjukkan eksistensinya kepada masyarakat Tosari yang sebagian besar beragama Hindu. Dokumentasi terhadap beberapa kegiatan-kegiatan yang ada sebagai berikut; (1) menata organisasi MUI berkerjasama dengan ormas keagamaan MWC NU Kecamatan Tosari, forum komunikasi diniyah Takmiliyah (FKDT) dengan membuat programprogram kegiatan baik jangka panjang maupun jangka pendek, (2) mengadakan kegiatan rutin yang bersifat keagamaan dan sosial, (3) melakukan penggalangan dana yang bertujuan untuk mengembangkan organisasi, (4) menjalin solidaritas antar anggota agar terciptanya keharmonisan sesame jamaah (muslim tengger), (5) adanya upaya untuk tetap bertahannya para jamaah (muslim tengger) di dalam binaan atau bimbingan MUI Kecamatan Tosari sebagai bentuk Eksistensi Muslim tengger.

\section{Model Mempertahankan Eksistensi Muslim Tengger}

Model mempertahankan eksistensi muslim di tengah keragaman pemeluk agama dan budaya lokal dalam kehidupan multikultural melalui; 1) muslim Tengger aktif mengikuti kegiatan-kegitan social yang diselenggarakan masyarakat Tengger, 2) muslim Tengger aktif mengikuti dan melaksanakan adat istiadat dan buadaya lakol masyarakat Tengger, dan 3) muslim Tengger turut serta gotong-royong membangun desa dan kampung.

Analisa model mempertahankan eksistensi muslim Tengger di tengah keragaman agama dan budaya lokal dalam kehidupan multicultural adalah sebagai berikut:

Pertama, muslim Tengger aktif mengikuti kegiatan-kegitan sosial yang diselenggarakan masyarakat Tengger. Masyarakat multikultiral adalah masyarakat yang terdiri dari berbagai elemen yang hidup dalam suatu lingkungan yang sama tanpa ada pembauran antara yang satu dengan yang lain. Dalam suatu masyarakat pasti akan menemukan banyak kelompok masyarakat yang mempunyai karakteristik berbeda-beda. Perbedaanperbedaan karakteristik itu berkenaan dengan tingkat diferensiasi dan stratifikasi sosial. Masyarakat seperti ini disebut sebagai masyarakat multikultural.

Kedua, muslim Tengger aktif mengikuti dan melaksanakan adat istiadat dan buadaya lakol masyarakat Tengger. Masyarakat Tengger memiliki 13 (tiga belas) adat istiadat atau budaya luar biasa dan 2 (dua) adat atau budaya biasa, secara lengkap diuraikan sebelumnya. Buah keaktifan muslim Tengger dalam mengikuti adat atau budaya masyarakat 
Tengger inilah umat Hindu lebih dekat dengan muslim Tengger dibandingkan dengan umat selain Islam. Umat Islam masuk kepanitiaan kegiatan-kegiatan baik kegiatan adat maupun budaya Tengger. Keaktifan inilah yang membuat tokoh-tokoh Hindu memberikan perhatian lebih kepada muslim Tengger baik dalam pembelaan kepentingan pribadi maupun syiar Islam. Misalnya dalam kebutuhan makam bagi muslim yang meninggal dunia, tokoh-tokoh Hindu membantu mempersiapkan lahan dan memperlancar pemakaman jenazah muslim walaupun dikubur di makam umum.

Ketiga, muslim Tengger turut serta gotong-royong membangun desa. Bangsa kita sebagai orang timur dan khususnya dalam dekade sejarah, sejak dulunya masyarakat pedesaan dan gampong mempertahankan gotong royong, dalam beberpa bulan sekali, namun seiring berjalannya waktu, dan masuknya budaya barat yang lebih mendorong masyarakat berkeinginan untuk ketidakmauan meninggalkan masalah perekonomian setelah masuknya masa industrialisasi, serta kesibukan masyarakat dengan menomorsatukan kepentingan pribadinya, lambat laun budaya gotong royong akan menipis.

\section{Proposisi}

Berdasarkan pada pembahasan atas temuan-temuan penelitian di atas, maka dapat dirumuskan sejumlah proposisi dalam penelitian ini, yaitu;

1. Jika proses pendidikan agama Islam multicultural dikembangkan dengan baik

dan mendapat dukungan dari pihak-pihak terkait dengan memperhatikan adat tradisi serta budaya lokal maka nilai-nilai pendidikan agama Islam di masyarakat muslim Tengger dapat diterima dengan baik dalam suasana toleransi yang hangat. Melalui dimensi hubungan seperti ini setiap individu dapat saling melengkapi dan menguatkan terhadap yang lain. ${ }^{6}$

2. Jika pengembangan nilai-nilai pendidikan Islam multicultural masyarakat muslim Tengger berperoses baik, maka akan dapat dipertahankan walaupun berada di tengah keragaman pemeluk agama dan budaya lokal, fakta-fakta terurai sebelumnya, bahwa muslim Tengger dapat diterima oleh masyarakat yang meyoritas berakidah Hindu.

3. Jika model pendekatan untuk mempertahankan nilai-nilai pendidikan agama Islam multikultural pada masyarakat muslim Tenggerdilakukan

${ }^{6}$ Robbayani, "Urgensi Pendidikan Agama Islam dalam Keluarga." Jurnal Ilmu Tarbiyah "At-tajdid” vol. 1. No 1, 2012, 100. 
dengan baik dan professional, maka pendekatan tersebut akan tidak siasia bahkan mendapat simpati dan dukungan masyarakat walau berbeda paham dan akidah.

\section{PENUTUP}

Alasan masyarakat Tengger menerima nilai-nilai pendidikan agama Islam multikultural dengan adat tradisi Tengger di tengah keragaman pemeluk agama dan bodaya lokal adalah sebagai berikut; (1) adat tradisi Tengger mengandung nilai-nilai multikulturalisme, (2) terdapat nilai-nilai kearifan lokal dalam toleransi beragama, (3) ada nilai-nilai multikulturalisme dalam keragamaan agama dan budaya lokal masyarakat Kecamatan Tosari, (4) kerukunan umat beragama di muslim Tengger sangat kokoh

Cara dimaksud: (1) mempertahankan nilai-nilai islam dalam keragamaan pemeluk agama dan budaya, (2) menjaga dinamika eksistensi muslim Tengger di tengah keragaman agama dan budaya, (3) memperkokoh toleransi umat beragama,(4) menyusun setrategi mempertahankan eksistensi muslim Tengger dalam keragaman agama dan budaya.

Model mempertahankan eksistensi muslim Tengger di tengah keragaman agama dan budaya adalah sebagai berikut; 1) muslim Tengger aktif mengikuti kegiatan-kegitan social yang diselenggarakan masyarakat Tengger, 2) muslim Tengger aktif mengikuti dan melaksanakan adat istiadat dan buadaya lakol masyarakat Tengger, dan 3) muslim Tengger turut serta gotong-royong membangun desa dan kampung.

\section{Buku}

\section{DAFTAR PUSTAKA}

Maslow, 2010, Motivation and Personality. Jakarta: Rajawali.

Muhaimin, 2008, Paradigma pendidikan Islam (upaya mengefektifkan pendidikan agama di sekolah). Bandung: Remaja Rosdakarya.

W. John Creswell, 2015. Penelitian Kualitatif dan Desain Riset: Memilih diantara Lima Pendekatan, Yogyakarta. Pustaka Pelajar.

Zuhairi Misrawi, 2010, Membumikan Toleransi al-Quran; Inklusivisme, Pluralisme dan Multikulturalisme, Jakarta: Moslem Moderate Society.

\section{Jurnal}

Robbayani, "Urgensi Pendidikan Agama Islam dalam Keluarga.” Jurnal Ilmu Tarbiyah "At-tajdid” vol. 1. No 1, 2012, 100. 


\section{Peraturan Perundang-undangan}

Peraturan Bersama Menteri Agama dan Menteri Dalam Negeri Nomor 9 Tahun 2006/ Nomor 8 Tahun 2006 Tentang Pedoman Pelaksanaan Tugas Kepala Daerah/Wakil Kepala Daerah dalam Pemeliharaan Kerukunan Umat Beragama, Pemberdayaan Forum Kerukunan Umat Beragama, dan Pendirian Rumah Ibadat.

Undang-Undang Dasar Negara Republik Indonesia Tahun 1945 